\title{
Longitudinal changes in nutritional habits of teenagers: differences in intake between schooldays and weekend days
}

\author{
BY BERTHEKE POST, HAN C. G. KEMPER \\ AND LUCIENNE STORM-VAN ESSEN \\ Working Group of Exercise Physiology and Health, University of Amsterdam, \\ Academic Medical Centre, Meibergdreef 15, 1105 AZ Amsterdam, The Netherlands
}

(Received 29 November 1985 - Accepted 4 July 1986)

\begin{abstract}
1. Longitudinal changes in nutritional habits were studied in Dutch adolescents from 12 to 17 years of age (131 girls and 102 boys). The dietary differences on schooldays and weekend days are reported.

2. In girls only small changes in nutritional habits were seen as they grew older. In boys there was a gradual increase in food intake with age.

3. Overall, higher nutrient intakes could be seen on weekend days. The energy intake on weekend days was consistently higher for girls and boys in all age-groups. The proportional intakes of fat and sugar were rather high, especially on weekend days. The alcohol consumption increased with age for girls as well as boys, and was for some individuals extremely high (boys) on weekend days.

4. The observed levels of intake compared with the recommendations showed a rather low intake of polyunsaturated fatty acids, polysaccharides and iron.
\end{abstract}

The nutritional survey reported in the present paper was part of a detailed multiple longitudinal study on growth and health of teenagers (Kemper et al. 1983). This investigation was designed to describe the course of the physical and mental development of teenagers, and to find out whether there is a period of deterioration in their state of health. For example, does the style of living change, particularly with respect to the daily food intake? Today there is an increasing awareness that the increasing costs of medical and health services must be controlled and that our society would be better served by devoting more effort to research into methods of primary prevention, i.e. changes from diagnosis to health promotion. Within the scope of this growth and health study it was considered important to have information about the quantitative and the qualitative aspects of nutritional habits of children in their teens. In the present paper the results of measurements of the daily diet are reported, especially the differences between schooldays and weekend days.

\section{SUBJECTS AND METHODS}

Subjects

In the study on growth and health of teenagers (Kemper et al. 1983) the measurements were taken during four consecutive years, from 1976 to 1980. Initially, the study involved about 600 pupils of the first and second forms of two secondary schools in The Netherlands. The group of pupils studied may not therefore be considered as representative of the Dutch teenage population in general. The pupils of these two schools have a level of intelligence above the average for their age. The parents of our subjects had a higher level of education, occupation and income than that found in an average Dutch family (Kemper, 1985). The pupils of one school (Amsterdam) were measured yearly and they are referred to as the longitudinal group.

The pupils were in the first and second forms at the start of the study at which time these two year-groups had average ages of 13 (first form) and 14 (second form) years. Because 


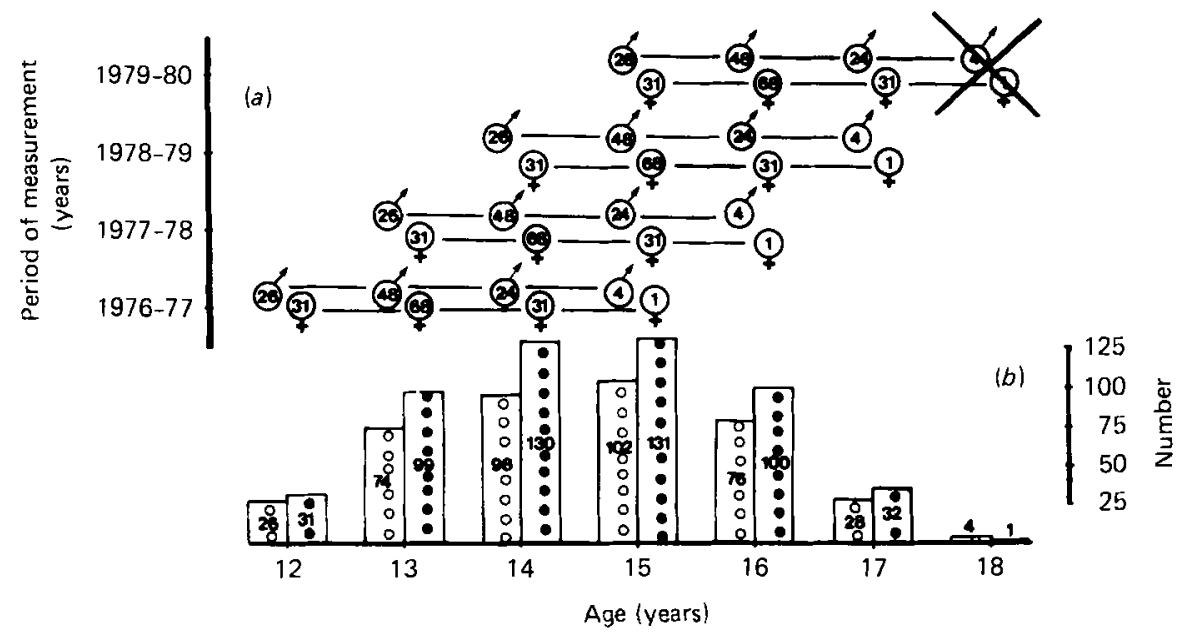

Fig. 1. (a) The number of boys and girls measured during the 4 years of the longitudinal study and (b) the total number of boys $(O)$ and girls $(O)$ per age-group.

of this difference of 1 year between the two groups of subjects (first and second forms) it was possible to check for interfering factors such as time of measurement effect and cohort effect that can present problems in interpreting the results of longitudinal research (Kemper \& Van't Hof, 1978). In the second school (Purmerend) with a comparable group of pupils, $25 \%$ of the group were selected at random each year and examined, so that in 4 years all pupils in this group were examined once: this is called the control group. In this design, comparison of the results for the longitudinal group with the results of the control group could give an indication of testing effects.

Over the duration of the study $24 \%$ of the pupils in the longitudinal group dropped out. Most of them (sixty-eight pupils) moved to a different type of school or out of the area. Only six pupils actually refused to continue participation. Finally the longitudinal group consisted of 131 girls and 102 boys, on whom the results are based. After checking for interfering effects the longitudinal data were arranged in age-groups irrespective of the year of measurement. In this way a developmental pattern over 6 years (from 12 to 18 years) could be covered, with most observations at the ages of 14 and 15 years. An overview of this final data arrangement is given in Fig. 1 which shows the number of girls and boys measured during the 4 years and the total number of girls and boys measured per age-group.

\section{Measurement of food intake}

The measurement of the food intake took place every year in the months January, February and March. Therefore seasonal bias is unlikely.

The schoolchildren in the present study did not have a fixed pattern of meals. In The Netherlands hot lunches are not served at school. Most of the pupils take sandwiches with them for lunch and have a hot meal at home in the afternoon. Because most teenagers are not particularly conscious of their eating and drinking habits we tried to find a special approach to determine the normal daily diet of the subjects with accuracy. A modification of the cross-check dietary history interview (Beal, 1967; Marr, 1971; Post \& Kemper, 1980) was used to ascertain the individual food intake. It lists a series of items, covering the entire range of foods and drinks, appropriate to a teenage population. In an interview with a nutritionist (the same throughout the study) all foods listed came under review with special reference to frequency and amounts. Information on foods eaten during regular meals as 
Table 1. The height, body-weight and percentage body fat of Dutch girls and boys in the longitudinal group

(Mean values with their standard errors)

\begin{tabular}{|c|c|c|c|c|c|c|c|}
\hline Age (years)... & & 12 & 13 & 14 & 15 & 16 & 17 \\
\hline \multicolumn{8}{|c|}{ Girls } \\
\hline No. & & 31 & 98 & 129 & 130 & 99 & 32 \\
\hline \multirow{2}{*}{ Height (m) } & Mean & $1 \cdot 55$ & 1.61 & 1.65 & $1 \cdot 67$ & 1.69 & $1 \cdot 68$ \\
\hline & SE & 0.011 & 0.007 & 0.006 & 0.006 & 0.007 & 0.013 \\
\hline \multirow[t]{2}{*}{$\mathrm{Wt}(\mathrm{kg})$} & Mean & $42 \cdot 2$ & $48 \cdot 0$ & $52 \cdot 0$ & 54.9 & $57 \cdot 4$ & 57.9 \\
\hline & SE & $\begin{array}{r}72 \\
1 \cdot 3\end{array}$ & 0.9 & 0.8 & 0.8 & 0.9 & $1 \cdot 2$ \\
\hline \multirow[t]{2}{*}{ Body fat $(\%)$} & Mean & $22 \cdot 8$ & $24 \cdot 5$ & $25 \cdot 6$ & $26 \cdot 6$ & $27 \cdot 4$ & $28 \cdot 1$ \\
\hline & SE & 0.9 & 0.5 & 0.4 & 0.4 & 0.5 & 0.6 \\
\hline \multicolumn{8}{|c|}{ Boys } \\
\hline No. & & 26 & 73 & 95 & 102 & 76 & 28 \\
\hline \multirow{2}{*}{ Height (m) } & Mean & $1 \cdot 51$ & 1.59 & 1.65 & $1 \cdot 73$ & 1.78 & $1 \cdot 81$ \\
\hline & $\mathrm{SE}$ & 0.014 & 0.008 & 0.008 & 0.007 & 0.007 & 0.008 \\
\hline \multirow[t]{2}{*}{ Wt (kg) } & Mean & $38 \cdot 4$ & $43 \cdot 4$ & $48 \cdot 9$ & 55.6 & 61.0 & 63.8 \\
\hline & SE & 0.9 & 0.7 & 0.8 & 0.8 & 0.9 & 1.8 \\
\hline \multirow[t]{2}{*}{ Body fat $(\%)$} & Mean & $15 \cdot 1$ & $16 \cdot 0$ & $16 \cdot 2$ & 16.0 & $16 \cdot 3$ & $17 \cdot 0$ \\
\hline & $\mathrm{SE}$ & 0.7 & 0.5 & 0.4 & 0.4 & 0.4 & 1.0 \\
\hline
\end{tabular}

well as between meals (so-called snacks) were collected separately for normal schooldays and for weekend days. The next step was to make inquiries about each food item. The subject was instructed to indicate the specified number of times per $d$, week or month the foods were consumed. Only the food items eaten at least twice monthly were recorded. The amounts were reported in household measures and common portion sizes. A variety of visual aids (such as glasses, bowls, spoons, and also polystyrene shapes of potatoes, apples and other fruits) were used to estimate quantities. Since it was assumed that teenagers do not necessarily know all the details regarding their food consumption, particularly with respect to its preparation, we also developed a questionnaire for the parents about details of several food items consumed by their children, e.g. skimmed or whole milk, kind and quantity of meat, addition of butter or sauce to vegetables and potatoes. For each individual all amounts were expressed in $\mathrm{g}$ for the five schooldays and the two weekend days.

All the dietary information was analysed using a computerized food-composition table (Cramwinckel et al. 1977), which was modified and supplemented as required. The following food characteristics were calculated and are discussed: energy, protein, fat, carbohydrate, dietary fibre, alcohol, minerals and vitamins. When it was useful, comparisons have been made with recommended dietary allowances (RDA) of The Netherlands Nutrition Council (Voedingsraad, 1978, 1981) and the Food and Agricultural Organization/World Health Organization (FAO/WHO) (1973).

\section{RESULTS}

In Table 1 the height, body-weight and percentage body fat of the longitudinal group are given. The mean body-weight of girls, between 12 and 17 years of age, increased from 42 to $58 \mathrm{~kg}$, and for boys from 38 to $74 \mathrm{~kg}$. Over the same period percentage fat, calculated from the sum of four skinfolds (Durnin et al. 1967), increased from 23 to $28 \%$ in the girls and from 15 to $17 \%$ in the boys.

\section{Testing effect}

Of the possible interfering factors on reported nutrient intakes, we found a testing effect in boys for energy, protein and carbohydrate intakes. This is illustrated for energy in Fig. 


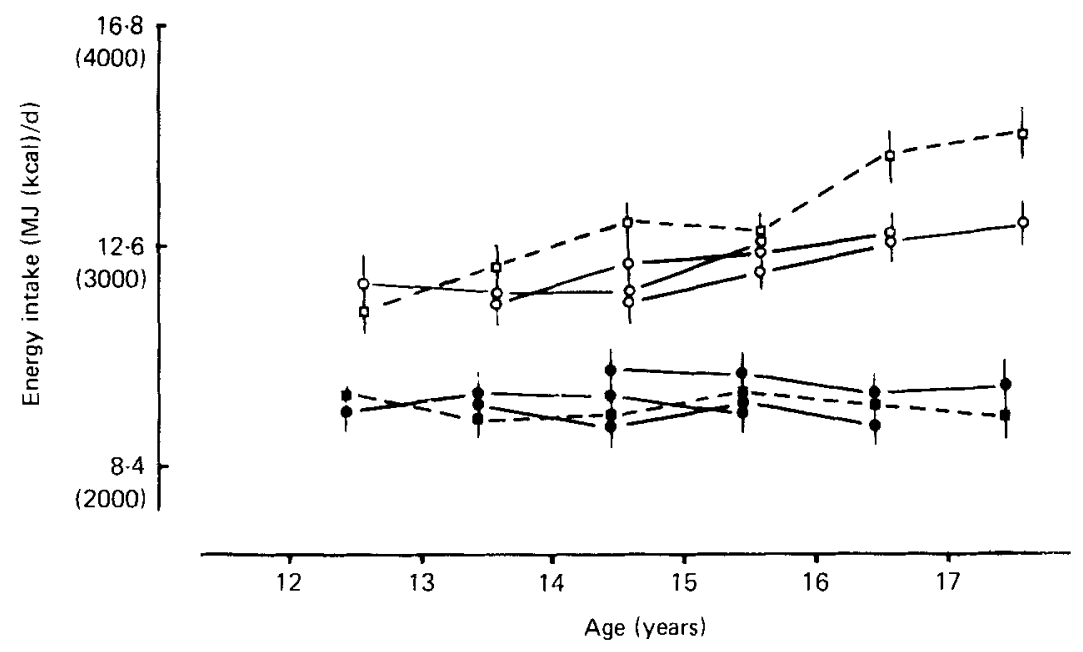

Fig. 2. Testing effect in the energy intake of boys illustrated by the mean scores of the three birth cohorts

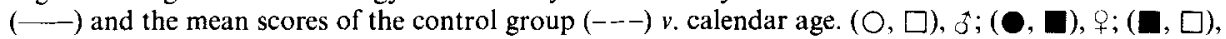
control groups; $(\boldsymbol{O}, O)$, longitudinal groups. Points are means with their standard errors represented by vertical bars.

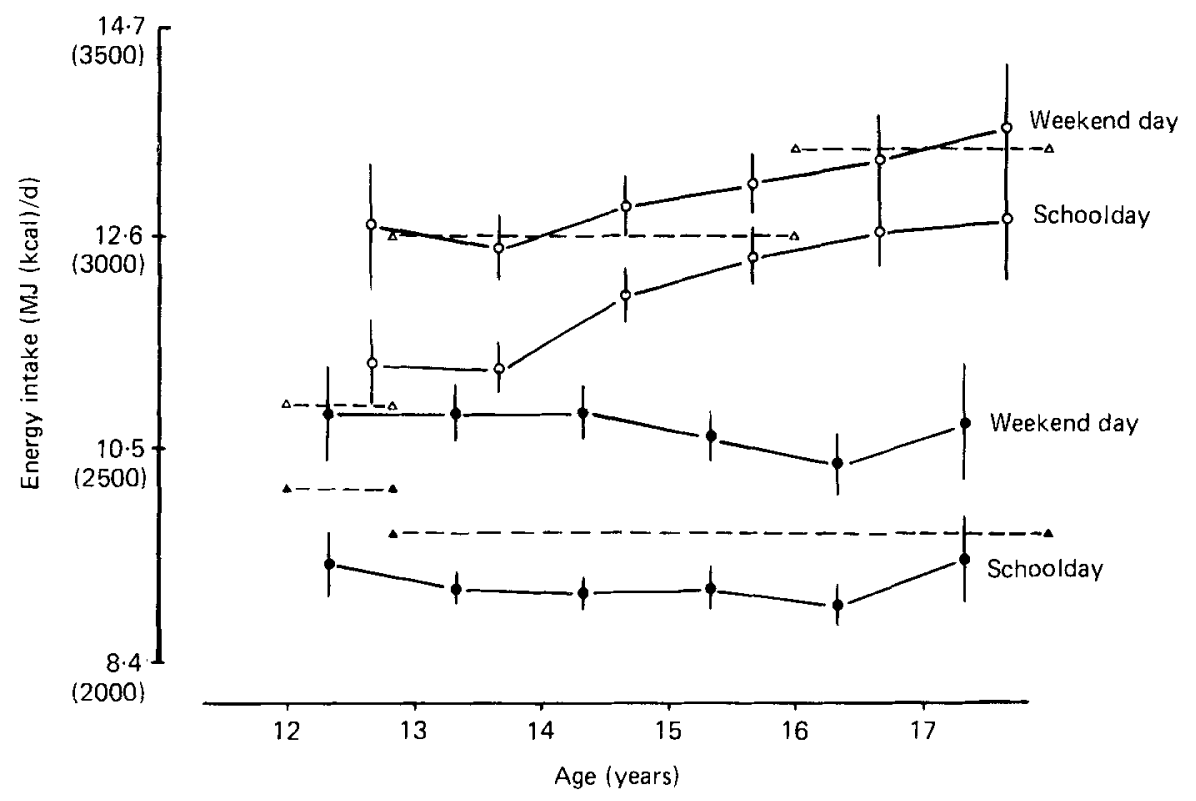

Fig. 3. Energy intakes for schooldays and weekend days in girls $(\boldsymbol{O}, \boldsymbol{\Delta})$ and boys $(O, \triangle) v$. calendar age $(\triangle---\triangle, \Delta---\Delta)$, Dutch recommended dietary allowances. Points are means with their standard errors represented by vertical bars.

2 where it can be seen that the increase in the mean energy intake over the study period was more pronounced in the control group than in the longitudinal group.

\section{Energy}

The average energy intakes of girls and boys on a mean schoolday and a mean weekend day are shown in Fig. 3. The daily intake for girls remained on the same level during the 


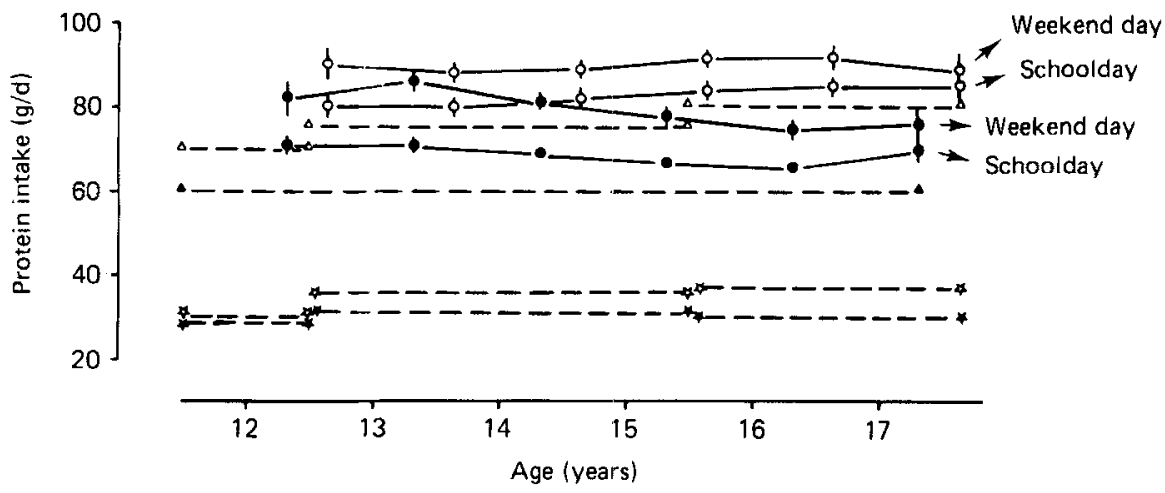

Fig. 4. Protein intake for schooldays and weekend days in girls $(\mathbf{O}, \mathbf{\Delta}, \downarrow)$ and boys $(\mathrm{O}, \square, \square) v$.

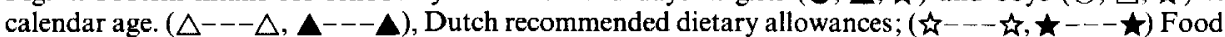
and Agricultural Organization/World Health Organization (1973) recommended allowances. Points are means with their standard errors represented by vertical bars.

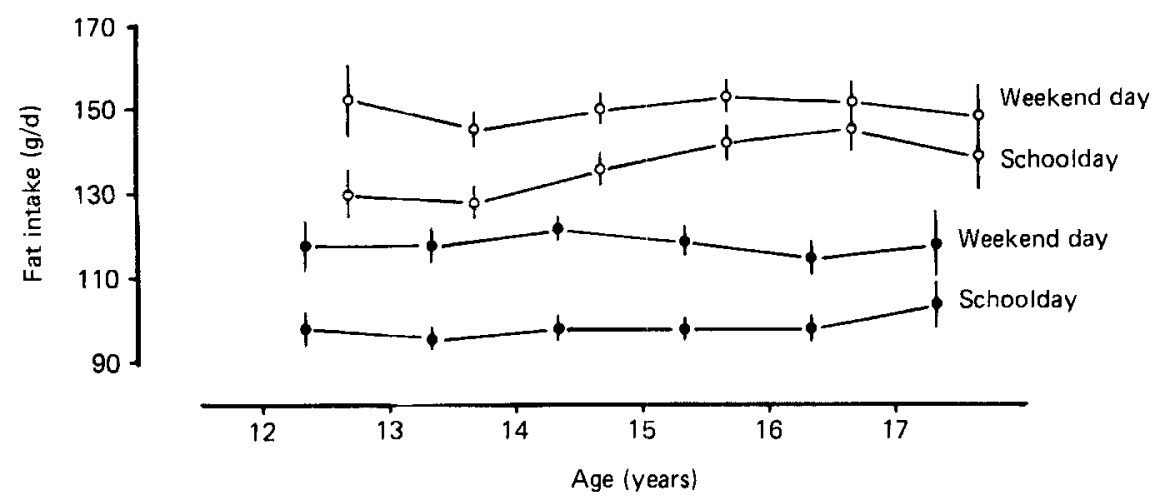

Fig. 5. Fat intake for schooldays and weekend days in girls (O) and boys (O) v. calendar age. Points are means with their standard errors represented by vertical bars.

whole age-range, whereas the intake for boys increased with age by about $1-1.5 \mathrm{MJ} / \mathrm{d}$ (on a mean schoolday as well as on a mean weekend day). On a weekend day girls and boys ate consistently more than on a schoolday. For girls the difference in intake was $1.4 \mathrm{MJ} / \mathrm{d}$; for boys the difference was $1.3 \mathrm{MJ} / \mathrm{d}$ at age $12-13$ years, decreasing to $0.8 \mathrm{MJ} / \mathrm{d}$ as they grew older (16-17 years old). Boys also ate consistently more than girls and the difference became more pronounced as they grew older in the course of the study. At age 12 years the difference was $21 \%$ on a schoolday and $17 \%$ on a weekend day. At age 17 years this difference had increased to $36 \%$ on a schoolday and $27 \%$ on a weekend day.

\section{Protein}

The mean dietary protein intake for girls and boys of 12-17 years is shown in Fig. 4. Girls had $10-15 \%$ higher protein intakes on weekend days compared with schooldays. The greatest differences were found in the age-group 13-15 years. Boys also showed a higher protein intake on a mean weekend day, but the difference decreased from $13 \%$ for $12-13$ years old to $5 \%$ for 17-18 years old, as the total protein intake on schooldays increased with age. The quality of the protein depends on the proportions of animal and vegetable protein in the daily diet. For both sexes the intake of vegetable protein remained almost the same on weekend days and schooldays. On a schoolday as well as on a weekend day 


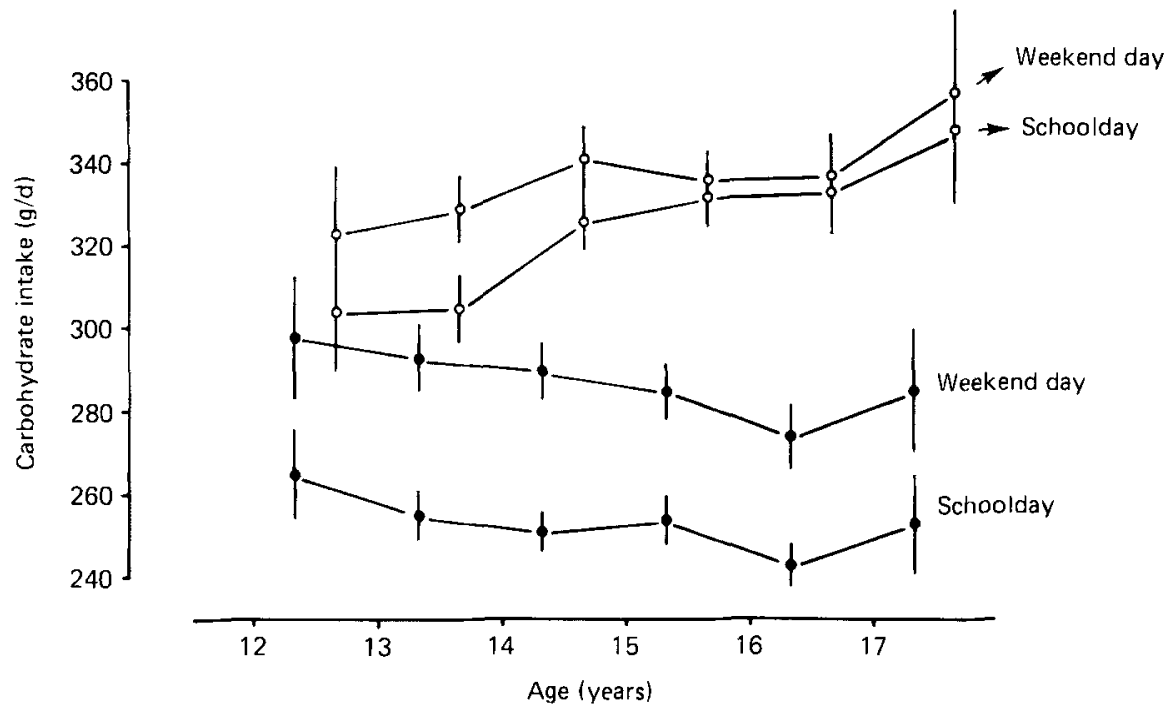

Fig. 6. Carbohydrate intake for schooldays and weekend days in girls $(O)$ and boys $(O) v$. calendar age. Points are means with their standard errors represented by vertical bars.

the intake of animal protein was almost twice that of vegetable protein. On weekend days the intake of animal protein was about $10 \mathrm{~g}$ more for girls, and $5 \mathrm{~g}$ more for boys, than on schooldays.

\section{Fat}

Fig. 5 shows the total fat intake on a mean schoolday and on a mean weekend day. For girls there was no age-effect. Boys increased their fat intake on a mean schoolday as they grew older. On a weekend day the mean fat intake for boys was about $7-15 \%$ higher, and for girls about $20 \%$ more than on a schoolday.

Dietary cholesterol tends to elevate serum cholesterol and polyunsaturated fatty acids (PUFA) tend to lower serum cholesterol. The cholesterol intake of the girls and boys was very much higher on weekend days than on schooldays. For girls the difference was about $60 \%$ and for boys it was about $50 \%$.

The intake of PUFA was almost equal between schooldays and weekend days for girls and boys. Girls in all age-groups had a mean intake of $15 \mathrm{~g}$ PUFA/d. Boys had about $20 \mathrm{~g} / \mathrm{d}$, slightly increasing with age.

\section{Carbohydrate}

Fig. 6 shows clearly the difference in carbohydrate intake between schooldays and weekend days for girls (12-15\% higher on weekend days). In boys this was true only for the youngest age-groups ( $7 \%$ higher). In general boys increased their carbohydrate intake with age, whereas older girls tended to decrease their carbohydrate consumption.

The intake of mono- and disaccharides (total sugar) supplied $24 \%$ of the total daily energy intake for the girls and $22 \%$ for the boys. In absolute values there was a tendency to decrease the intake with age for girls, but for boys there was an increase with age.

\section{Dietary fibre}

The dietary fibre intakes for the youngest girls and boys were 23 and $25 \mathrm{~g}$ respectively with no difference between weekend days and schooldays. As they grew older the intake increased 
Table 2. Percentage of pupils who report consuming alcoholic beverages, by age, for schooldays and weekend days

\begin{tabular}{cccccc}
\hline & \multicolumn{2}{c}{ Girls $(n 131)$} & & \multicolumn{2}{c}{ Boys $(n 102)$} \\
\cline { 2 - 3 } \cline { 5 - 6 } Age (years) & Schoolday & Weekend day & & Schoolday & Weckend day \\
\hline $12-13$ & - & 6 & & - & 4 \\
$13-14$ & 4 & 9 & & 7 & 15 \\
$14-15$ & 7 & 22 & & 19 & 28 \\
$15-16$ & 14 & 33 & & 42 & 51 \\
$16-17$ & 16 & 44 & 50 & 68 \\
$17-18$ & 41 & 62 & & 50 \\
\hline
\end{tabular}

Table 3. Alcohol intake ( $\mathrm{g}$ ) of girls and boys who report consuming alcohol, for a mean schoolday and a mean weekend day

(Mean values with their standard errors)

\begin{tabular}{|c|c|c|c|c|c|c|c|c|}
\hline \multirow[b]{3}{*}{ Age (years) } & \multicolumn{4}{|c|}{ Girls $(n 131)$} & \multicolumn{4}{|c|}{ Boys $(n 102)$} \\
\hline & \multicolumn{2}{|c|}{ Schoolday } & \multicolumn{2}{|c|}{ Weekend day } & \multicolumn{2}{|c|}{ Schoolday } & \multicolumn{2}{|c|}{ Weekend day } \\
\hline & Mean & $\mathrm{SE}$ & Mean & SE & Mean & $\mathrm{SE}$ & Mean & $\mathrm{SE}$ \\
\hline $12-13$ & - & - & 1 & 1.0 & - & - & 5 & - \\
\hline $13-14$ & 1 & 0.3 & 6 & 1.4 & 1 & 0.3 & 4 & 0.9 \\
\hline $14-15$ & 2 & 0.6 & 5 & 1.0 & 2 & 0.6 & 6 & $1 \cdot 2$ \\
\hline $15-16$ & 3 & 0.8 & 6 & 1.0 & 8 & $3 \cdot 7$ & 15 & 3.4 \\
\hline $16-17$ & 3 & 1.0 & 10 & 1.4 & 12 & 2.6 & 27 & $4 \cdot 2$ \\
\hline $17-18$ & 4 & 0.5 & 11 & 1.7 & 17 & $6 \cdot 0$ & 29 & $5 \cdot 8$ \\
\hline
\end{tabular}

a little, but more markedly on schooldays, so that on a weekend day the intake was about $5 \mathrm{~g}$ lower.

\section{Alcohol}

The intake of alcohol increased with age, especially during the weekend. The consumption of alcoholic drinks on schooldays started at about age 15-16 years at which time the mean consumption was $0.4 \mathrm{~g} /$ schoolday for girls and $1.5 \mathrm{~g} /$ schoolday for boys. The amounts increased to $1.5 \mathrm{~g} /$ schoolday for girls of 17-18 years and 8.6 g/schoolday for boys of the same age. At the weekend, 12-13-year-old girls and boys only consumed an average of $0 \cdot 1$ and $0.2 \mathrm{~g} / \mathrm{d}$ respectively, but there was a large increase in this level so that by 17-18 years of age average consumption by the girls was $7 \cdot 1 \mathrm{~g}$ and by the boys $19.6 \mathrm{~g} /$ weekend day.

Because there was a large number of 'non-drinkers' the distribution of alcohol intake was skewed and mean alcohol intake of all subjects does not give a good indication of the true pattern. Therefore the percentage of alcohol consumers was determined (Table 2) and their mean alcohol intake per mean schoolday and weekend day (Table 3) calculated. The mean alcohol intake increased with age, on schooldays and especially on weekend days, for girls and boys. In general, both girls and boys reported an increasing consumption of light alcoholic drinks (such as beer and wine) as they grew older.

\section{Minerals}

The calcium intake for girls on schooldays was about $900 \mathrm{mg}$ in all age-groups. On a weekend day the intake was somewhat higher, by between 40 and $120 \mathrm{mg}$, depending on 


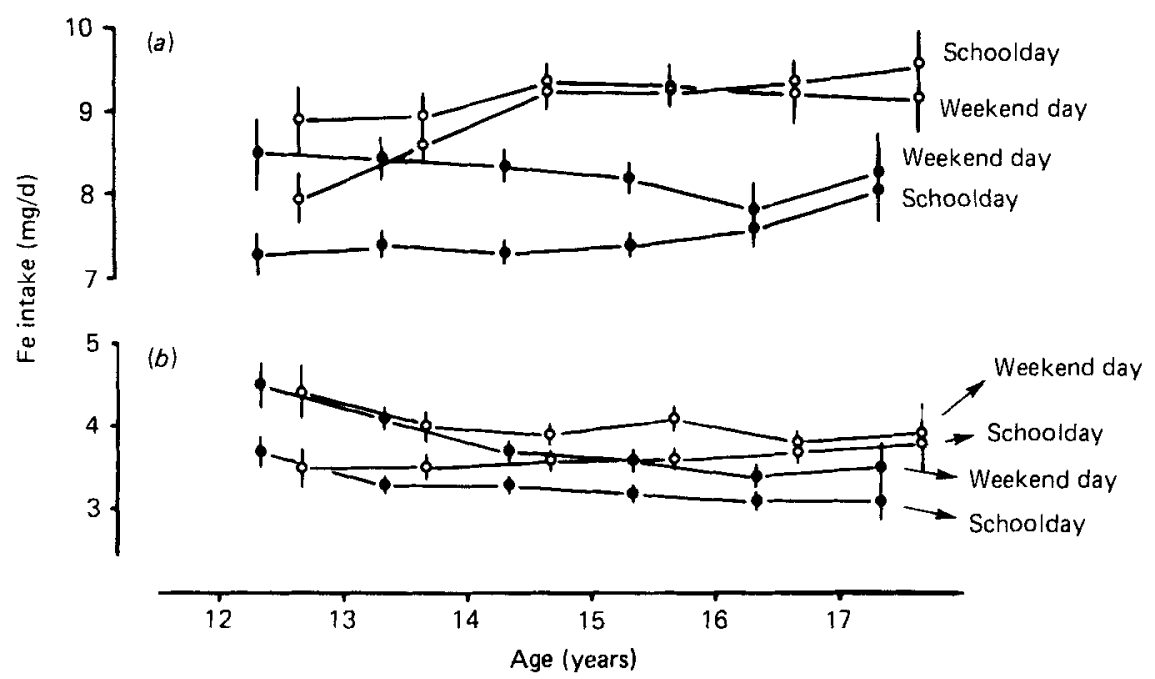

Fig. 7. Iron intake in (a) non-haem and $(b)$ haem compounds for schooldays and weekend days in girls (O) and boys $(O) v$. calendar age. Points are means with their standard errors represented by vertical bars.

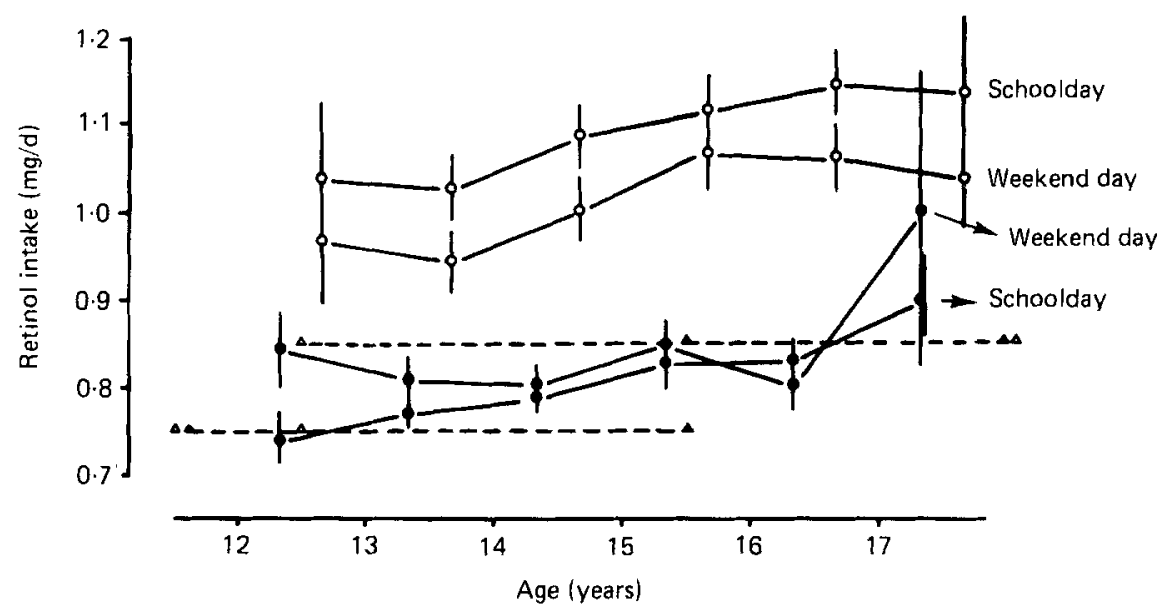

Fig. 8. Retinol intake for schooldays and weekend days in girls $(\boldsymbol{O}, \boldsymbol{\Delta})$ and boys $(O, \triangle) v$. calendar age. $(\triangle--\triangle, \Delta--\Delta)$ Dutch recommended dietary allowances. Points are means with their standard errors represented by vertical bars.

age. Boys had a mean daily $\mathrm{Ca}$ intake of $1090 \mathrm{mg}$ on schooldays and weekend days. Only in the higher age groups did this intake increase in the weekend days by about $100 \mathrm{mg} / \mathrm{d}$.

In the present study the total daily iron intake of 12-13-year-old girls was $11.5 \mathrm{mg}$, decreasing to about $11.0 \mathrm{mg}$ as they grew older. Boys of 12-13 years had an intake of $12 \mathrm{mg}$ $\mathrm{Fe} / \mathrm{d}$ and this increased to $13.2 \mathrm{mg} / \mathrm{d}$ in the $17-18$ year olds. Only the youngest age-groups showed higher total $\mathrm{Fe}$ intakes on weekend days, the difference being about $16 \%$ for both girls and boys. The Fe intake was divided into haem-Fe compounds and non-haem-Fe compounds. The intakes of non-haem-Fe were about two times as high as the amount of haem-Fe (Fig. 7). The haem-Fe intake for girls on a mean weekend day was about $0.5 \mathrm{mg}$ higher compared with schooldays irrespective of age. In boys this difference was only seen in the youngest group where the intake was about $1 \mathrm{mg}$ higher on weekend days. The non-haem-Fe intake for girls was about $1 \mathrm{mg}$ higher at weekends in the first four age-groups 


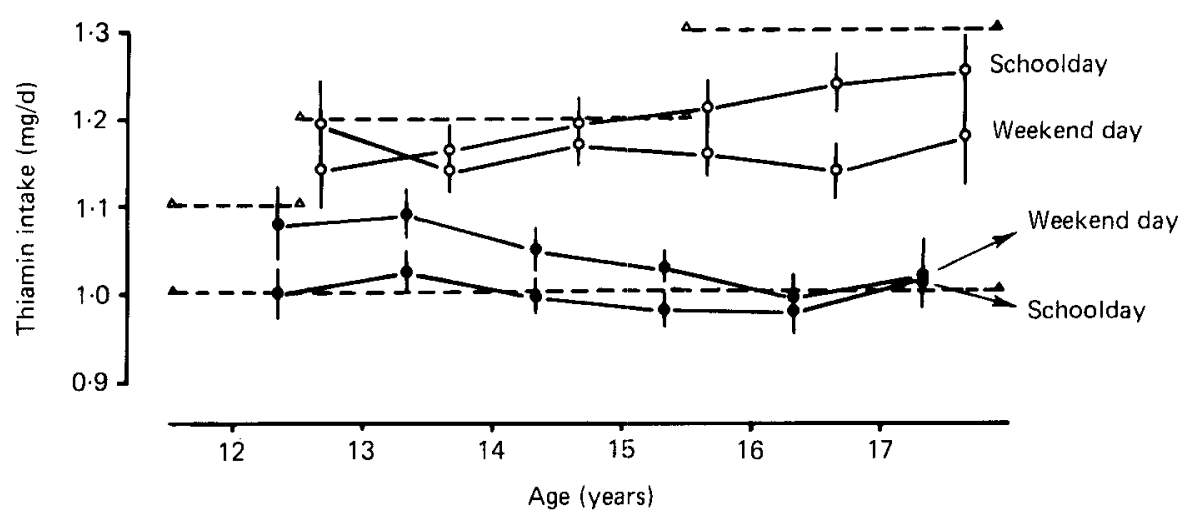

Fig. 9. Thiamin intake for schooldays and weekend days in girls $(\mathbf{O}, \mathbf{\Delta})$ and boys $(O, \triangle) v$. calendar age. $\left(\triangle^{--}-\triangle, \Delta---\mathbf{\Delta}\right)$ Dutch recommended dietary allowances. Points are means with their standard errors represented by vertical bars.

but equal in the older groups. In contrast the boys initially showed a lower intake on weekend days (about $0.9 \mathrm{mg}$ ), but after the age of 15-16 years the non-haem-Fe intake increased and was $0.4 \mathrm{mg}$ higher than that on a schoolday.

\section{Vitamins}

In girls retinol (vitamin $\mathrm{A}$ and $\beta$-carotene) intake only showed a difference between schooldays and weekend days in the youngest and oldest age-groups (about $0.1 \mathrm{mg}$; Fig. 8 ). Boys had, on a weekend day, a lower retinol intake of about $0 \cdot 1 \mathrm{mg}$ than on a schoolday for the whole age-range.

The thiamin intake of girls was about $1.0 \mathrm{mg} / \mathrm{schoolday}$ and remained quite stable in all age-groups (Fig. 9). On a weekend day the intake of 12-13-year-old girls started on the somewhat higher level with a tendency to decrease with age. For boys 12-14 years old, the intake was $1.1 \mathrm{mg}$ thiamin/schoolday and tended to increase for 15-18 year olds to $1.2 \mathrm{mg} / \mathrm{d}$. Fig. 9 shows that on a weekend day the mean intake fluctuated somewhat with age, being about $1.2 \mathrm{mg}$ with lower intakes than on schooldays.

The pyridoxine intake of girls on schooldays $(1.2 \mathrm{mg})$ did not change with age (Fig. 10). On the weekend days there was a lower intake, and this tended to decrease a little up to 16 years of age. Boys had similar constant pyridoxine intakes with lower intakes at the weekend.

The ascorbic acid intake increased a little with age for girls. Boys had fluctuating intakes in the different age-groups. As Fig. 11 shows, the ascobic acid intakes on weekend days were much lower than those on schooldays for both girls (about $20 \mathrm{mg}$ ) and boys (about $30 \mathrm{mg}$ ).

\section{DISCUSSION}

\section{Measurement of food intake}

In a preliminary investigation we tried to find out which of the methods, the $24 \mathrm{~h}$ recall or the cross-check dietary-history method, was the best to estimate the food intake of children in the age-groups 12-18 years old (Post \& Kemper, 1980). The cross-check dietary-history method gave the smaller intra-individual differences between test-retest measurements, and these differences were not significant. In addition it was less timeconsuming and so this was the method we finally chose.

The food-intake interview used in the present study has many similarities with the 


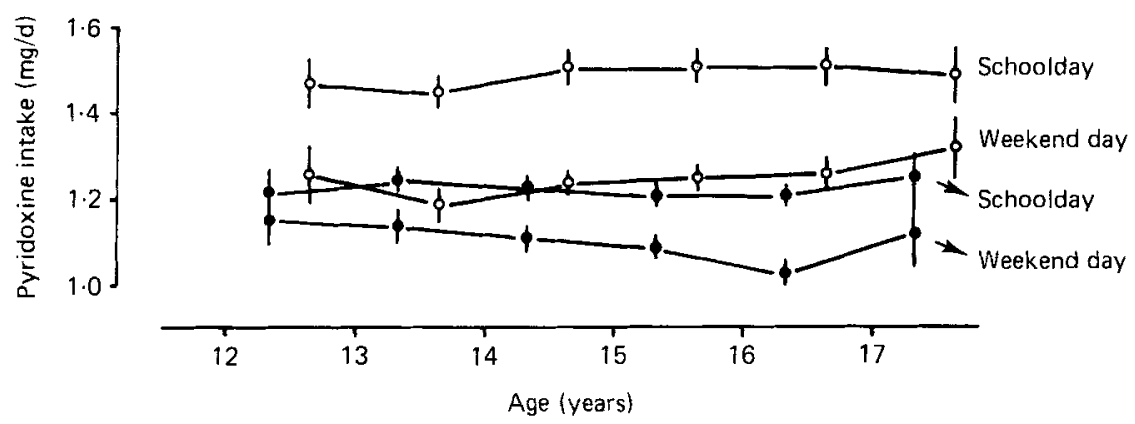

Fig. 10. Pyridoxine intake for schooldays and weekend days in girls $(O)$ and boys $(O) v$. calendar age. Points are means with their standard errors represented by vertical bars.

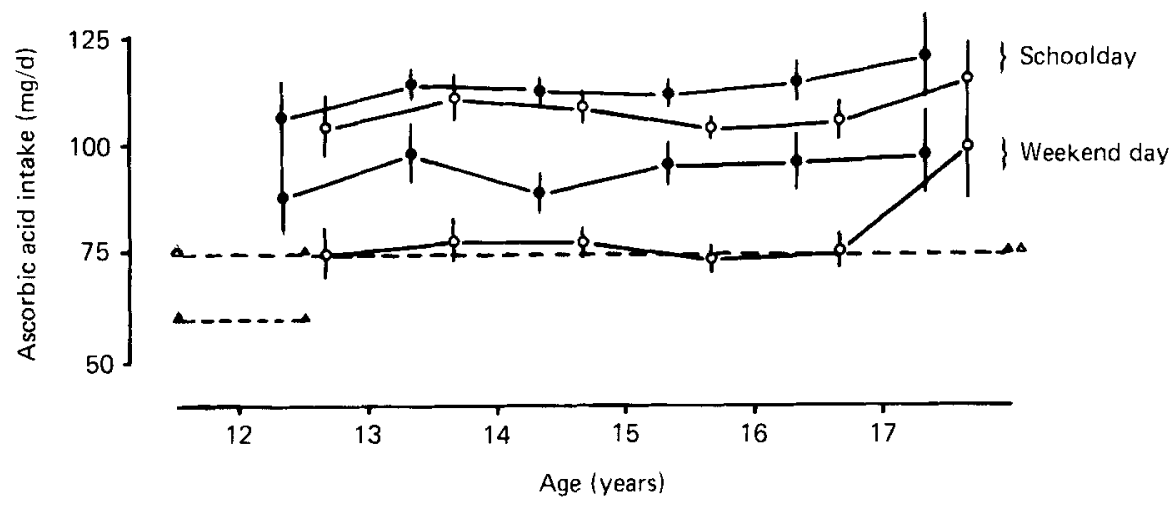

Fig. 11. Ascorbic acid intake for schooldays and weekend days in girls $(\boldsymbol{O}, \boldsymbol{\Delta})$ and boys $(O, \triangle) v$. calendar age. $(\triangle---\triangle, \mathbf{\Delta}---\mathbf{A})$ Dutch recommended dietary allowances. Points are means with their standard errors represented by vertical bars.

dietary history interview method described by Van Staveren (1985). Van Staveren (1985) demonstrated that the protein intake estimated from an interview agreed with the nitrogen excretion in the urine.

\section{Test effects}

Test effects were only found in boys for energy, protein and carbohydrate intake. It is possible that the lower amounts found in the longitudinal group were caused because the boys became more aware of what they were eating or they were less inclined to overestimate their intake in the course of the study, or both. In the control school (Purmerend) the subjects had higher protein intakes than of those in the longitudinal group from the start of the study. This school effect might be related to the somewhat higher socio-economic background of the parents in Purmerend. A longitudinal study of Hackett et al. (1984), for example, indicated a positive correlation between social class and protein intake.

\section{Food intake}

In the literature there are few studies describing the differences between schooldays and weekend days, thus in order to compare our findings with the literature we calculated the intake per mean weekday:

$$
\frac{(5 \times \text { mean schoolday })+(2 \times \text { mean weekend day })}{7} .
$$


Nutritional habits of teenagers

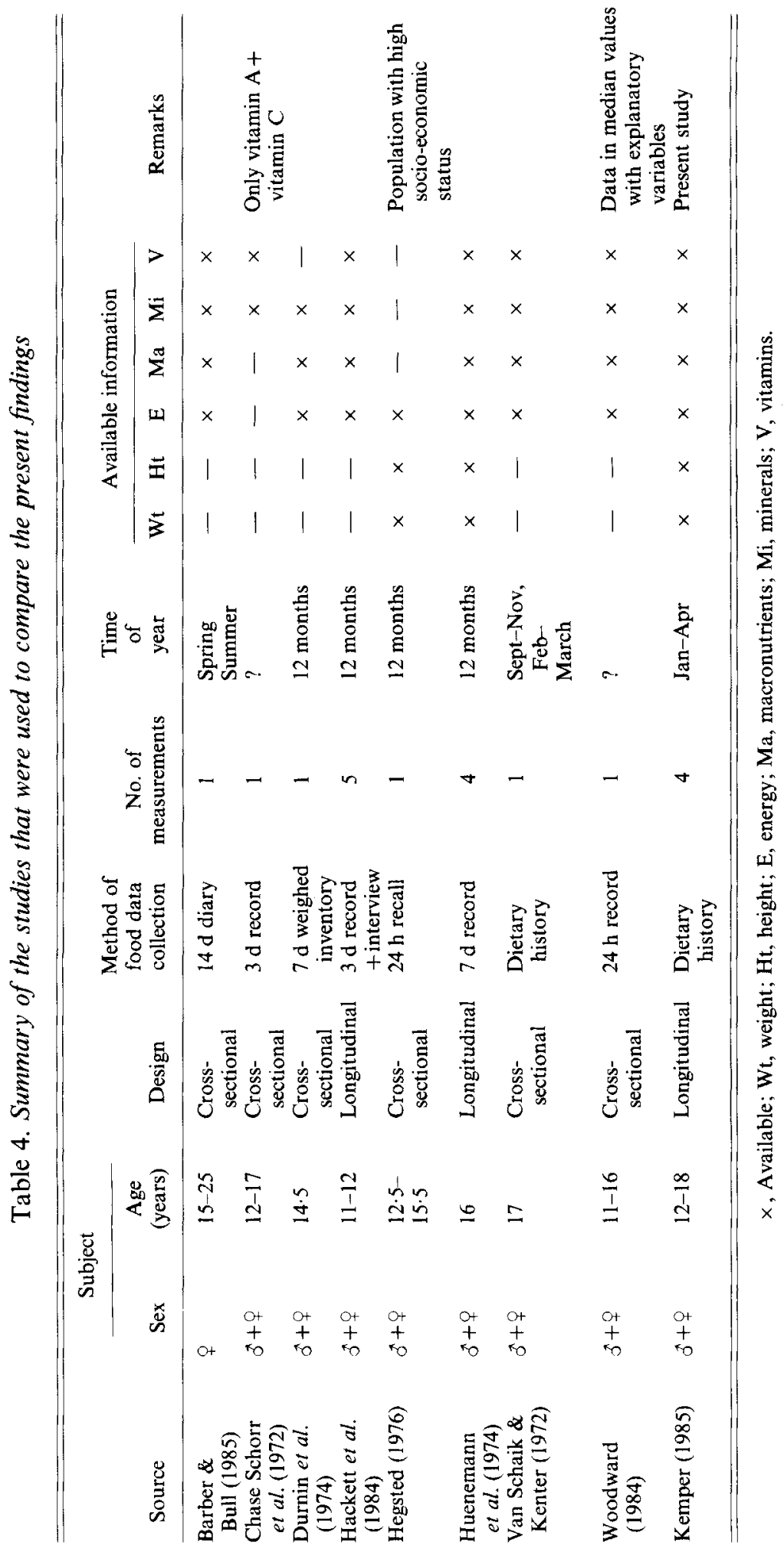


Table 4 summarizes the studies with which our results are compared. However, it must be kept in mind that differences in results may be caused by: (1) different methods of information collection; such as records over 3 or $7 \mathrm{~d}$, recall over $24 \mathrm{~h}$, dietary history, or combinations of these methods; (2) differences in design: longitudinal $v$. cross-sectional data collection; (3) differences in the time of year (season); (4) differences in weight and height of the populations.

Compared with the longitudinal study of Huenemann et al. (1974), the energy intake seemed to be equal for boys (aged 16 years) but higher by about $1 \mathrm{MJ} / \mathrm{d}$ for girls (aged 16 years) in the present study. The energy intakes for 12-16-year-old girls and boys in the Ten State Nutrition Survey (Hegsted, 1976) seem very similar to our findings. Durnin et al. (1967) found, for 14-year-old Glasgow schoolchildren in 1964, a mean daily energy intake which is almost identical to the intakes of the 14-year-old girls and boys in the present study. However, in their 1971 study, Durnin et al. (1974) found somewhat lower intakes for both girls (-1.1 MJ) and boys (-1.3 MJ). Also, Hackett et al. (1984) described a nutritional longitudinal survey in England with lower energy intake for girls (about $-1.4 \mathrm{MJ}$ ) and boys (about $-2 \cdot 2 \mathrm{MJ}$ ) aged 11-12 years, compared with the 12-year-olds in the present study. In contrast Barber \& Bull (1985) reported a mean intake of $9.3 \mathrm{MJ} / \mathrm{d}$ in $15-18$-year-old English girls (not on a slimming diet), which is similar to that found in the present study. In Britain, energy intakes have been decreasing over the past decades, and this is thought to be a reflection of lower energy expenditure (Buss, 1982). In The Netherlands, dietary surveys among teenagers are scarce, therefore it is difficult to recognize differences in energy and nutrient intakes over the past years. Although, Van Schaik \& Kenter (1972) reported the same daily energy intakes for 17 -year-old girls $(9 \cdot 8 \mathrm{MJ})$, they found much higher intakes for 17-year-old boys (14.5 MJ) compared with the present study (13.0 MJ).

Woodward (1984) described energy intakes among Tasmanian teenagers (12-15 years old), expressing the results as median values (equal to the 50 th percentile) rather than mean values. On analysis the median values of energy intake for the groups of girls and boys in the present study were almost equal to the mean values, and so it seems unlikely that this difference in expression could account for the somewhat higher energy intakes of our 12-13-year-old boys $(11 \cdot 2 \mathrm{MJ} / \mathrm{d})$ compared with the Tasmanian boys $(10.8 \mathrm{MJ} / \mathrm{d})$. By age 13-14 years, the intakes between the two groups were comparable.

Considering the Dutch RDA and the recommendations of the FAO/WHO (1973), the mean daily energy intake of those in the present study, seemed to be not too high (Fig. 12). The inter-individual differences, however, were great (one individual may consume twice the amount taken by another). For girls there seemed to be no change in energy intake with age. This fits rather well with the Dutch RDA. For boys there was an increase with age, which coincides with the recommendations of the FAO/WHO (1973) but not with the Dutch RDA. Girls increased their body fat by $5 \%$ but the daily energy expenditure of the girls remained fairly constant with age (Verschuur \& Kemper, 1985). However, the energy expenditure per $\mathrm{kg}$ body-weight decreased for girls with age. It is not clear whether the girls with increased body fat were the same ones who decreased their energy expenditure or, possibly, that they underestimated their energy intake.

The protein intakes of the girls (70-75 g/mean weekday) and boys ( $80-85 \mathrm{~g} /$ weekday) are not dissimilar to, and lie about the mid-point of, those of the studies listed in Table 4 , with the notable exception of the extremely high intakes of $125 \mathrm{~g} / \mathrm{d}$ reported by Huenemann et al. (1974) for 16-year-old boys in the USA.

Since vegetable protein possesses a lower nutritive value than animal protein, relatively more is required. Thus we computed the total animal protein intake $/ \mathrm{kg}$ body-weight of the $10 \%$ of the girls and boys with the lowest protein intakes. These girls and boys, $12-13$ years old, showed an intake of about $1 \mathrm{~g}$ animal protein $/ \mathrm{kg}$ body-weight per $\mathrm{d}$, which is equal to the requirements for this age-group (de Wijn \& Van Staveren, 1984). As they grew older, 


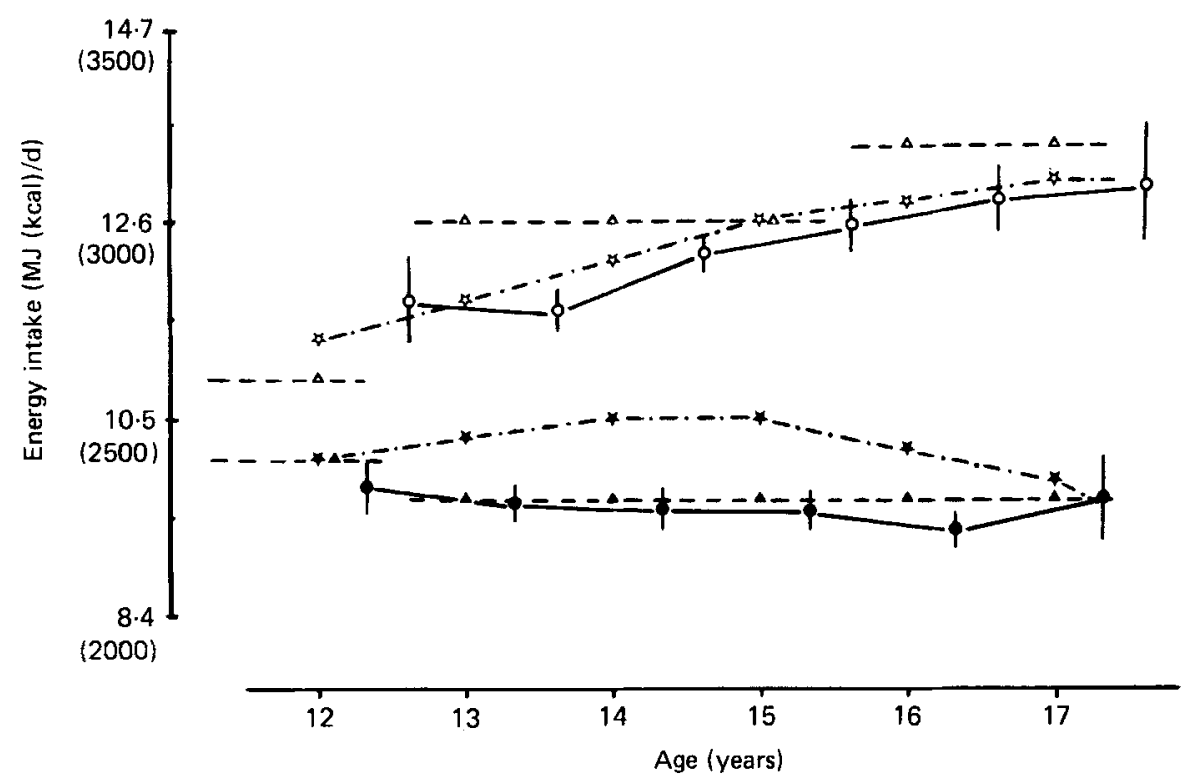

Fig. 12. Daily energy intake of girls $(\boldsymbol{O}, \boldsymbol{\Delta}, \star)$ and boys $(O, \triangle$, $)$. v. calendar age. $(\Delta---\Delta, \mathbf{\Delta}---\mathbf{\Delta})$, Dutch recommended dietary allowances; ( $-. .-\ldots, \cdot-.+$ ), Food and Agriculture Organization/World Health Organization (1973) recommended dietary allowances. Points are means with their standard errors represented by vertical bars.

these amounts decreased steadily to about $0.5 \mathrm{~g} / \mathrm{kg}$ for the $17-18$ year olds, which is far below the recommendations. These lower animal protein intakes were not compensated by more vegetable protein.

In the control school (Purmerend), there was a generally higher intake of protein by girls as well as boys at all ages. This might be related to differences in the socio-economic background of the families between the two schools with possible influence on the eating habits. Durnin et al. (1974) found markedly lower protein intakes by boys in the lowest social classes.

The fat intake of the 16-year-old American girls studied by Huenemann et al. (1974) was $90 \mathrm{~g} / \mathrm{d}$ and for boys $145 \mathrm{~g} / \mathrm{d}$. In a study of Scottish children, Durnin et al. (1974) reported a fat intake for 14-year-old girls of $93 \mathrm{~g} / \mathrm{d}$ and for boys of $115 \mathrm{~g} / \mathrm{d}$. In an earlier Dutch survey (Van Schaik \& Kenter, 1972), 17-year-old girls had a mean daily fat intake of $100 \mathrm{~g}$ and the boys of $145 \mathrm{~g}$. The amounts of fat consumed by girls in the present study were higher than claimed in the American study but equal to those reported by Van Schaik \& Kenter (1972). The fat intakes by boys were similar in all the studies. Our findings agreed also with those observed in a study on the fat consumption of the total population of The Netherlands (de Wijn \& Van Staveren, 1984) and also with those of Durnin et al. (1974) in Scotland. High fat intakes are implicated in the aetiology of atherosclerosis which may be initiated in early childhood. There is a tendency for populations consuming high levels of fat to exhibit higher serum lipid levels. The high intake of cholesterol in the weekend days and the low intake of PUFA by the girls and boys indicates that more attention should be paid to dietary fat intake in this age group.

Over $20 \%$ of energy was supplied by sugar and this was also found by Hackett et al. (1984) for children of about 12 years of age. This percentage increases the possibility of development of dental caries but may also be associated with other health problems such as overweight and heart disease.

Van Vliet et al. (1982) describes, in another Dutch longitudinal group, high percentages 
of alcohol drinkers: $30 \%$ of 13-year-old girls and boys and $80 \%$ at the age of 18 years. Another Dutch study (Schuurman, 1983) reports the proportion of alcohol drinkers among 13 to 18 -year-old schoolchildren as being $11 \%$ of the girls and $26 \%$ of the boys. There is no report of differences between age groups, but the percentages given are much lower than those in the present study.

In comparison with the record method used by Van Vliet et al. (1982) and Schuurman (1983), our interview method was conducted on an individual basis by an experienced nutritionist and this may give a more realistic impression of alcohol consumption. However, the moral and emotional significance of alcohol consumption is probably much higher than for most other nutritional items and this may give rise to some additional inaccuracies in reported consumption. Notwithstanding this reservation, it is interesting to note that girls and boys who reported consuming more than $10 \mathrm{~g}$ alcohol/weekday had significantly higher intakes of energy and most other nutrients compared with non-drinkers. This is in contrast to the assumption, which is sometimes made, that alcohol consumers have lower nutrient values in their diets compared with non-drinkers. Further, the distribution of alcohol consumption is such that $5 \%$ of boys reported consuming $30 \mathrm{~g} /$ weekday at age 16-17 years, rising to $50 \mathrm{~g} /$ weekday at 17-18 years. If these reported consumptions are accurate it is clear that there may be serious adverse effects on health. Even if they do include some element of exaggeration they still point to a perception of desirability and acceptability, at least amongst the immediate peer group, which should give cause for concern.

Allowing for the fact that adolescence is a period of rapid growth and $\mathrm{Ca}$ is needed mainly for bone growth, we can conclude that the intake of $\mathrm{Ca}$ in the groups was sufficient.

The Fe intake for the girls were on a somewhat higher level (about $2.0 \mathrm{mg} / \mathrm{d}$ ) than in most studies (Chase Schorr et al. 1972; Van Schaik \& Kenter, 1972; Huenemann et al. 1974; Hackett et al 1980 ) but $0.5-1.5 \mathrm{mg} / \mathrm{d}$ lower than that in Tasmanian girls (Woodward, 1984) and comparable to the Fe intakes reported by Durnin et al. (1974). The boys had Fe intakes almost equal to those reported by Van Schaik \& Kenter (1972), higher than the findings of Hackett et al. (1980) and Barber \& Bull (1985), but lower than those in the other studies (about $2 \cdot 0-4.0 \mathrm{mg} / \mathrm{d}$ ). However, although the average for the girls and boys in the present study met the recommended levels of Fe intake, this conceals the fact that many children had much lower intakes than recommended. On the 25 th percentile, for example, Fe intakes for girls and boys were only 60 and $70 \%$ respectively of the recommended levels. Barber \& Bull (1985) also described an intake of $70 \%$ of the recommended Fe for 15-18-year-old girls. Our impression is that serious attention should be paid to the daily $\mathrm{Fe}$ intake of adolescents. However, this must take account of known mechanisms of adaptation to high and low intakes, and also distinguish between haem and non-haem compounds.

The mean retinol intakes of the girls, including the tendency to increase retinol intake with age, appear sufficient to achieve recommended levels. The difference in retinol intake between girls and boys can be explained by the total fat intake (boys about $30 \mathrm{~g} / \mathrm{d}$ more than girls, mostly due to the extra butter and margarine intake).

The thiamin intakes in the present study were similar to those reported in the literature, except for American boys who have almost $0.5 \mathrm{mg}$ higher thiamin intakes/d (Van Schaik \& Kenter, 1972; Huenemann et al. 1974). The recommended values take into account the energy intake and are set at $0.4 \mathrm{mg} / 4.2 \mathrm{MJ}$. Considering the total energy intake of our adolescents, the needs for thiamin are met perfectly (girls $0.44 \mathrm{mg} / 4.2 \mathrm{MJ}$ and boys $0.40 \mathrm{mg} / 4.2 \mathrm{MJ}$ ). Most carbohydrate-rich foods (polysaccharides) are also usually rich in thiamin, but when eating habits change to the use of more refined carbohydrates (in the present study these sometimes accounted for about $50 \%$ of the total carbohydrate intake) 
it may be possible that the thiamin intake will reach borderline values. Nevertheless, in our group of adolescents the mean intake was sufficient.

In the present study, girls had lower riboflavin intakes $(0.4 \mathrm{mg})$ than American girls (Huenemann et al. 1974) but higher (0.4 mg) than other Dutch girls (Van Schaik \& Kenter, 1972). For boys Huenemann et al. (1974) mentioned $1.2 \mathrm{mg}$ higher riboflavin intakes than those in the present study, and Van Schaik \& Kenter (1972) 0.4 mg higher. However, taking into account the protein intake or the energy intake, or both, the intakes of riboflavin in our study appear satisfactory.

The daily ascorbic acid intake in girls was higher $(20-25 \mathrm{mg} / \mathrm{d})$ than that reported in the literature (Chase Schorr et al. 1972; Van Schaik \& Kenter, 1972; Huenemann et al. 1974) and more than $50 \mathrm{mg}$ higher than in the longitudinal study of Hackett et al. (1984). For boys the intakes were almost similar, except for the children in the study by Hackett et al. (1984). These high intakes may be due to the Dutch habit of a dinner with vegetables and potatoes, besides which there is an abundance of fruit available.

\section{Conclusions}

It is necessary to take into account that the dietary intake measured by the cross-check dietary-history interview in teenagers shows possible testing effects, at least in boys, as a result of the repeated measurements.

The teenage girls had a constant energy intake as they grow older, with consistently higher intakes on a weekend day than on a schoolday. The total energy intake of boys increased gradually with age, on a mean schoolday as well as on a mean weekend day; in all age-groups there was a slightly higher intake on weekend days. In relation to the fat intake, special attention should be paid to the very high cholesterol intake during the weekends.

Another point of concern is alcohol consumption. Most of the consumption of alcoholic drinks was concentrated at the weekend and in such high quantities (especially in boys) that this might be seen as detrimental to health.

Overall, higher nutrient intakes could be seen on weekend days, and this was most evident for energy intake (protein, fat, carbohydrate and alcohol intake). In comparison with RDA we must conclude that the daily food intake of teenagers did not contribute enough PUFA and polysaccharides. The observed levels of intake of vitamins and mineral were sufficient. However, the $\mathrm{Fe}$ intake for girls was borderline.

\section{REFERENCES}

Barber, S. A. \& Bull, N. L. (1985). Ecology of Food and Nutrition 16, 161-169.

Beal, V. A. (1967). Journal of the American Dietetic Association 51, 426-432.

Buss, D. H. (1982). Nutrition and Food Science 74, 12-14.

Chase Schorr, B., Sanjur, D. \& Erickson, E. C. (1972). Journal of the American Dietetic Association 61, 415-420.

Cramwinkel, A. B., Doesburg, W. H., Hezemans, A. M., Lemmens, W. A. J. \& Reintjes, A. G. W. (1977). Voeding 38, 168-176.

de Wijn, J. F. \& Van Staveren, W. A. (1984). De voeding van elke dag. Utrecht: Bohn, Scheltema \& Holkema. Durnin, J. V. G. A., Lonergan, M. E., Good, J. \& Ewan, A. (1974). British Journal of Nutrition 32, 169-179.

Durnin, J. V. G. A. \& Rahaman, M. M. (1967). British Journal of Nutrition 21, 681-689.

Food and Agriculture Organisation/World Health Organization (1973). Energy and Protein Requirements. Technical Report Series no. 522. Geneva: WHO.

Hackett, A. F., Rugg-Gunn, A. J., Appleton, D. R., Parking, J. M. \& Eastoe, J. E. (1984). Annals of Human Biology 11, 545-553.

Hegsted, D. M. (1976). In Nutrient Requirements of Adolescents, pp. 107-126 [J. I. McKigney and H. N. Munro, editors]. Cambridge, Mass.: MIT Press.

Huenemann, R. L., Hampton, M. C., Behnke, A. R., Shapiro, L. R. \& Mitchell, B. W. (1974). Teenage Nutrition and Physique. Springfield, Illinois: Charles C. Thomas.

Kemper, H. C. G. (editor) (1985). Growth, Health and Fitness of Teenagers. Longitudinal Research in International Perspective. Medicine and Sport Sciences, vol. 20. Basel: Karger. 
Kemper, H. C. G., Dekker, H., Ootjers, G., Post, B., Ritmeester, J. W., Snel, J., Splinter, P., Storm-van Essen, L. \& Verschuur, R. (1983). Growth and Health of Teenagers. Amsterdam: University of Amsterdam.

Kemper, H. C. G. \& Van't Hof, M. A. (1978). European Journal of Pediatrics 179, 147-155.

Marr, J. W. (1971). World Review of Nutrition and Dietetics 13, 105-164.

Post, G. B. \& Kemper, H. C. G. (1980). Voeding 41, 123-129.

Schuurman, M. I. M. (1983). Tijdschrift voor Sociale Geneeskunde 61, $23-27$.

Van Schaik, Th. F. S. M. \& Kenter, H. A. (1972). Voeding 32, 577-604.

Van Staveren, W. A. (1985). Food intake measurements: their validity and reproducibility. PhD Thesis, Landbouw Hogeschool, Wageningen.

Van Vliet, H. C. A. M., Hofman, A., Muller, L. \& Valkenburg, H. A. (1982). Tijdschrift voor Sociale Geneeskunde 60, 876-879.

Verschuur, R. \& Kemper, H. C. G. (1985). Medicine and Sports Science 20, 169-187.

Voedingsraad (1978). Voeding 39, 325-332.

Voedingsraad (1981). Nederlandse Voedingsmiddelentabel. The Hague: Voorlichtingsbureau voor de Voeding. Woodward, D. R. (1984). British Journal of Nutrition 52, 21-32. 